\title{
PERSISTENCE OF OUTSTANDING PERFORMANCE AND SHAREHOLDER VALUE AMONG DIVERSIFIED FIRMS: THE IMPACT OF PAST PERFORMANCE, EFFICIENT INTEGRAL CAPITAL MARKET, AND RELATEDNESS OF BUSINESS SEGMENTS
}

Federico Marinelli 


\title{
PERSISTENCE OF OUTSTANDING PERFORMANCE AND SHAREHOLDER VALUE AMONG DIVERSIFIED FIRMS: THE IMPACT OF PAST PERFORMANCE, EFFICIENT INTEGRAL CAPITAL MARKET, AND RELATEDNESS OF BUSINESS SEGMENTS
}

\author{
Federico Marinelli ${ }^{1}$
}

\begin{abstract}
The research domain that attempts to study the relationship between diversification and performance has not yet reached definitive and interpretable findings, and recent studies challenge the existence of a "diversification discount" and explain it partially by a data artefact. None of these studies centered their research on the question: does a specific performance pattern exist among diversified firms? This research aims to identify persistence in performance heterogeneity by measuring the shareholder value creation of diversified firms using alternative indicators other than the excess value methodology. It also aims to measure the impact on the performance according to the degree of efficiency of the internal capital market and the degree of relatedness among business segments. A sample of 164 diversified firms with turnover greater than $\$ 1$ billion during the 1999-2006 period is examined. Because of the presence of the firm's specific effect and the length of the time series, the persistence performance is tested through the instrumental variables (IV) system generalized method of moments (GMM) dynamic panel data and the persistence of shareholder value creation, and destruction is estimated according to different estimators from top tercile and lower tercile portfolios of diversified firms. Some diversified firms persistently create value as well as beat the market index while others persistently underperform. Finally, if the efficiency of the internal capital market gives certain explanatory power of the performance pattern, but limited compared to the past performance, important insights might be drawn from the findings that diversified firms with segments in many unrelated industries perform better than others in few industries or with a high number of segments; hence, the inverted-U curvilinear relationship between diversification and performance is here not confirmed.
\end{abstract}

${ }^{1}$ Researcher, IESE

Keywords: Diversification, performance persistence, internal capital market, relatedness of the business segments. 


\section{PERSISTENCE OF OUTSTANDING PERFORMANCE AND SHAREHOLDER VALUE AMONG DIVERSIFIED FIRMS: THE IMPACT OF PAST PERFORMANCE, EFFICIENT INTEGRAL CAPITAL MARKET, AND RELATEDNESS OF BUSINESS SEGMENTS}

\section{Introduction}

The research domain that attempts to study the relationship between diversification and performance has not yet reached definitive and interpretable findings to determine if diversification strategy creates or destroys value. Despite this lack of consensus, empirical results have identified mechanisms to understand the "dark and bright sides" ${ }^{1}$ of the relationship between diversification and value creation, and the recent MctA wave of $2006^{2}$ indicates that firms still consider diversification as a path of value creation. In the field of finance, all of the studies centered on the following research question: is a single segment better off alone or within a conglomerate? Hence the research question was to identify if "on average" diversification creates or destroys value through a "chop-shop" approach. Lang and Stulz (1994) and Berg and Ofek (1995) found a consistent diversification discount, but later other authors argue that the discount is attributable to factors other than diversification (Campa and Kedia, 2002; Graham, Lemmon and Wolf, 2002; Villalonga, 2004a), and that previous attempts to assess the diversification discount in U.S. stock markets are flawed because of their reliance on reported business segments, and finally diversification creates value (Villalonga, 2004b). In the field of strategic management, the research question is focused on the identification of the "type of diversification," comparing diversified firms among them rather

\footnotetext{
${ }^{1}$ Khanna and Tice (2001) published their empirical findings on the positive effects related to the internal capital market explaining shareholder value creation under the title, "The Bright Side of Internal Capital Markets." In contrast, Sharfstein and Stein (2002) published empirical findings on the "pervert relationships" between shareholder value destruction and the internal capital market under the title, "The Dark Side of Internal Capital Markets." In both studies, empirical findings are consistent and developed in different contexts and focus on different phenomenon, hence they cannot be considered in competition. The conclusion that can be drawn is that there is not a "fixed effect" or phenomenon that "ex-ante“ allows to identify if the diversification per se creates or destroys value. It can be both and depends on how the specifics mechanisms related to this type of firm are maximized and the drawbacks minimized. The role of the top management seems to be strongly critical in the determination of the relationship diversification and value creation.
}

\footnotetext{
${ }^{2}$ Financial Times, December 21, 2006, "M\&A in 2006 Beats Tech Boom.”
} 
than developing a benchmark based on single segment firms. Palich, Cardinal, and Miller (2000), studying 55 quantitative studies of the diversification performance linkage, confirm that this linkage appears to have an inverted-U curvilinear relationship with performance, but the choice of measurement method of diversity or "relatedness" presents scholars a degree of subjectivity (Martin and Sayrak, 2003) hence the possibility to influence research results (Hall and John, 1994; Robin and Wieserma, 2003).

In this paper, rather than pursue an additional analysis to determine if "on average" diversification creates or destroys value, or to determine a representative index of "relatedness," it examines the tales of the distribution of the diversified firms to discover if there exists a specific performance pattern among diversified firms. When studying if diversification creates or destroys value, it seems more appropriate to take inspiration from the performance pattern of private equity (LBO): both models of firms follow a value maximization behavior, target poor performing companies, possess higher management capabilities than single segment firms to improve productivity, transfer knowledge management among segments of business, and finally benefit from high availability of funds for investments from both internal and external sources.

LBO performance has a specific performance pattern compared to mutual funds, leading to the question if "on average" the risk-adjusted performance of LBO is better to mutual funds; this is not probably the most important question to ask when making investments, but rather its performance persistence (Kaplan and Schoar, 2005).

This research aims to identify the persistence in performance heterogeneity by measuring the shareholder value creation of diversified firms using portfolio management techniques as an alternative indicator rather than the excess value methodology, and finally it aims to measure the impact on performance according to the degree of efficiency of the internal capital market and to the degree of relatedness among business segments.

An important persistence of performance is found in both accounting and market valuation measurements: some diversified firms persistently outperform their industry and beat the financial markets, while others persistently underperform. This research contributes to the understanding of the relationship between diversification and value creation or destruction through the perspective of the persistence of performance among diversifiers. Through this perspective, diversification can be considered as a consistent and persistence strategy to generate shareholder value that goes far beyond the degree of efficiency in the funds allocation process and the degree of relatedness among business segments.

\section{Review of the Literature}

The research domain that attempts to study the relationship between diversification and performance has not yet reached definitive and interpretable findings to determine if diversification strategy creates or destroys value despite the substantial number of empirical studies in both finance and strategic management (Martin and Sayrak, 2003). 


\section{Finance literature}

In finance literature most of these studies were centered on the research question: is a segment of business better off alone or within a conglomerate? Does this enables researchers and scholars to determine if "on average" diversification creates or destroys shareholder value?

Business segments within a conglomerate are supposed to benefit from the internal capital market, the headquarters is considered an effective financial intermediary through "winner picking" behavior (Williamson, 1975; Stain, 1997): the business segment benefits of higher rights control over the projects allowing for better information flow, higher assets redeployability and relaxation of credit constraints (Gertner, Sharfstein, and Stein, 1994). These benefits are supposed to offset the internal capital market flip side identified as the reduction of manager entrepreneurial incentive, the effort dilution factor and agency argumentation of onthe-job-consumption (Jensen, 1986) in which projects receive a lower level of funding than they could obtain standing alone because of the cross-subsidiarization in which good performing divisions subside poor performing divisions destroying shareholder value (Lang and Stulz, 1994; Berg and Ofek, 1995; Denis, Danis, and Sarin, 1997; Raian, Servaes, and Zingales, 2000; Sharfstein and Stain, 2000).

In order to answer that specific question, Lang and Stulz (1994), through a firm's industry adjusted Tobin's $q$ and Berg and Ofek (1995) through an excess value methodology, find that the value of the diversified firms is "on average" lower than the comparable portfolios of specialized firms, finding a diversification discount explained by inefficiency of the internal capital market. They conclude that diversification is not a successful path to higher performance because the value of the diversified firm is less than the sum of its parts by an average discount factor of 13-15\% (Berg and Ofek, 1995).

The method of portfolios of specialized firms or "pure play firms" (Lang and Stulz, 1994; Berg and Ofek, 1995) suffers from several drawbacks, such as the sample selection (Campa and Kedia, 2002; Villalonga, 2004a), measurement errors and data artefact (Graham, Lemmon, and Wolf, 2002; Schoar, 2002; Mansi and Reeb, 2002; Villalonga, 2004b; Emms and Kale, 2006; Stowe and Xing, 2006). Once these biases are corrected, the diversification discount becomes very small or even turns into a premium. Campa and Kedia (2002) and Villalonga (2004a) find that the diversification discount was explained by endogeneity (diversifying firms are poor performers prior to conglomeration) and once the endogeneity is corrected, they find empirical evidence that diversification might be a value-enhancing strategy. Graham, Lemmon, and Wolf (2002) and Emms and Kale (2006) found that target firms were already discounted firms, hence the comparison between divisions of conglomerate and stand-alone firms overestimates the magnitude of the diversification discount. Mansi and Reeb (2002) argue that measurements of the firm's value based on book value of debt would systematically undervalue diversified firms, ${ }^{3}$ and Stowe and Xing (2006), using the excess value methodology, find that part of the diversification discount was explained by controlling the firm's growth opportunities, ${ }^{4}$

\footnotetext{
${ }^{3}$ They argue that diversification leads to lower firm's risk and found that book value of debt is a more downward biased proxy of the market value of debt for diversified relative to undiversified firms.

${ }^{4}$ Stowe and Xing (2006) used the excess value method of Berg and Ofek (1995), but the single segment counterpart is the firm in the same industry that has the closest growth opportunity (proxy for growth opportunity is the ratio capital expenditure to total asset).
} 
concluding that growth opportunities might account for at least one part of the diversification discount. Villalonga (2004), using excess value methodology, finds that the diversification discount was due to a data artefact (over-evaluation of the assets and sales industry multiples). She merges the BITS database on business segments with Compustat, and the discount becomes a premium. Following this line of empirical findings, Santalo and Becerra (2008) show that the effect of diversification on performance is not homogeneous across industries: diversified firms perform better in industries with a small number of non-diversified competitors.

If evidence at market valuation level is inconclusive, when the unit of analysis is shifted from shareholder value to firm's productivity (proxy of performance), research has also produced mixed results, and in addition, the number of studies is limited. Schoar (2002) finds that plants within diversified firms are, on average, more productive than plants in comparable single segment firms about a coefficient of 7\%. However, in this process of becoming more diversified, firms suffer a net reduction in productivity because of the "new toy effects": the productivity increase of newly-acquired plants does not offset the decrease in productivity of the incumbent plants. In contrast, Maksimovic and Phillips (2002) find, consistent with a negative excess value of diversified firms, that productivity of conglomerate firms is lower than single-segment firms of similar size, but this difference was mainly driven by smaller peripheral segments that show significantly lower productivity than do main segments. ${ }^{5}$

\section{Strategic management literature}

In contrast to finance, in strategic management field, most studies were centered on the research question that certain types of diversification lead to distinctive competence (Rumelt, 1974, 1982; Bettis, 1981; Palepu, 1985; Wernerfelt and Montgomery, 1988). Here the research question is focused on the identification of the "type of diversification" comparing diversified firms among them rather than developing a benchmark based on single segment firms building "pure play firm" (Lang and Stulz, 1994; Berg and Ofek, 1995). Palich, Cardinal, and Miller (2000), studying 55 quantitative studies of the diversification performance linkage, confirm that this linkage appears to have an inverted-U curvilinear relationship with performance: a positive effect occurs as firms move from a single business strategy to a related diversification strategy, but negative effects occur as firms move from a related strategy to an unrelated strategy. The key question here seems to be the choice of measurement method of diversity or "relatedness" that influences research results (Hall and John; 1994; Robin and Wieserma, 2003). Attempts to measure the extent and type of firm diversity have followed two main avenues: on one extreme there are simple but objective, and replicable indicators (e.g. continuous measurement developed from SIC code like Hertfindahl index) but with the shortcoming not to fully tap into the dimension of relatedness, and on the other extreme, there are more sophisticated indicators that are able to represent in more detail the degree of relatedness among business units. To this second line of approach their relatedness constructs are based on cross-business synergies arising from: e.g. product relatedness (Rumelt, 1974) manufacturing relatedness (John and Harrison, 1999), technological relatedness (Robins and Wiersema, 1995; Silverman, 1999), REtD relatedness (Chatterjee and Wernerfelt, 1991) marketing relatedness (Capron and Hulland, 1999), advertising relatedness (Chatterjee and Wernerfelt, 1991), managerial relatedness (Ilinitch and Zeithaml, 1995; Prahalad and Bettis, 1986), human resources relatedness (Farjoun, 1994),

\footnotetext{
${ }^{5}$ Maksimovic and Phillips (2002) attempt to explain this difference arguing that in their measure of productivity, a fixed effect is included and that samples are different.
} 
and resource-based view relatedness (Markides and Williamson, 1994). Robin and Wieserma (2003) raised the issue related to the "content validity" of the related diversification indexes, and Tanriverdi and Venkatraman (2005), point out the difference between potential relatedness and actual relatedness: potential synergies may not be exploited by the firm, hence when using potential relatedness as proxy for actual relatedness, the interpretation of results might be difficult.

To summarize, in both fields of research, empirical findings that attempt to answer the question (i) if a business segment is better off within a diversified firm or standing alone and (ii) what type of relatedness increases firm performance, have not yet completely reached their objective. But on the other hand, they have highlighted consistent and specific characteristics of diversified firms.

On "the bright sid,", diversified firms benefit from an efficient ${ }^{7}$ internal capital market (Williamson, 1975; Shin and Stulz, 1988; Stain, 1997) and from cheaper access to the external source of funds (Mansi and Reeb, 2002, 2006; Peyer, 2002), especially in situations when there exists a higher information asymmetry between the corporate headquarter and the external capital market (Maksimovic and Phillips, 2002; Khanna and Tice, 2002; Campello, 2002; Guedji and Scharfstein, 2004; Hyland and Diltz, 2002). In addition, diversified firms that follow a neoclassic value maximization model by searching for new growth opportunities (Goold and Campbell, 1987; Chandler, 1991; Campa and Kedia, 2002; Maksimovic and Phillips, 2002; Schoar, 2002; Stowe and Xinx, 2006), maximize synergies across business (Palich, Cardinal, and Miller, 2000), acquire poor performing firms (Graham, Lemmon, and Wolf, 2002; Emms and Kale, 2006) and improve the productivity of target companies through higher management capabilities than single-segment firms (Schoar, 2002). ${ }^{8}$

On "the dark side" of diversification, empirical findings have shown its drawbacks (in terms of value destruction) especially driven by agency argumentations that deviate funds allocation to their best uses (Jensen, 1986; Denis, Danis, and Sarin, 1997; Sharfstein and Stain, 2000; Raian, Servaes, and Zingales, 2000; Hyland and Dilz, 2002), or by the development of business segments with the absence of potential synergies (Palich, Cardinal, and Miller, 2000) or because the firm is too big and becomes unmanageable (Stain, 1997).

\section{Research Question and Structure of the Paper}

Goold and Campbell's (1987) research on the role of corporate headquarters and how it adds value to subsidiaries through management approach, strategy, management philosophy, and

\footnotetext{
6 The authors mention the definition of Zaller and Carmines (1980), which describes the content validity as: "fundamentally content validity concerns the extent to which a set of items taps the content of some domain of interest. To the degree that the items reflect the full domain of content they are said to be content-valid."

${ }^{7}$ Shin and Stulz (1988) define the internal capital market efficient if (1) it gives priority in the allocation of funds to the segment with best investment opportunities.;(2) if it makes that segment's investment less sensitive to its own cash flow; and (3) if the allocation of funds to a segment falls when other segments have better investment opportunities.
}

${ }^{8}$ She found that expanding focused firms are less productive after diversification than non-expanding focused firms. 
individual personalities, is consistent with the empirical findings of the last 15 years: diversified firms seem to be much more complex than single-segment firms with fewer credit constraints. Moreover, there is a lack of consensus in the identification of standard indicators of relatedness, and from which type of data it should be computed. Because of this complexity, to study diversified firms by searching in general a "rule for riches" for single business segment or for highly relatedness portfolio of business segments may be misleading; in addition, the effect on diversification is not homogeneous across industries (Santalo and Becerra, 2008). It might be more appropriate to identify what performance pattern belongs to diversified firms and then how the internal capital market and the degree of relatedness among business segments affects it and to what extent. Intuitively, in order to study when diversification creates or destroys value, it seems more appropriate to take inspiration from the performance pattern of private equity funds (LBO). Under this view, with few exceptions, like the investment time horizon, the legal structure or personnel policies, both private equity and diversified firms have strong similarities: (i) both models of firms follow a value maximization behavior; (ii) target poor performing companies; (iii) possess higher management capabilities than single segment firms to improve productivity; (iv) transfer knowledge management among business segments; and (v) finally benefit from high availability of funds for investments from both internal and external sources.

Kaplan and Schoar (2005), studying private equity LBO performance, find specific performance patterns of LBO compared to mutual funds: "on average" the risk-adjusted performance of LBO is slightly less than the market index, but in opposition with mutual funds in which persistence of return has been difficult to detect, LBO funds that outperform the market also show a substantial risk-adjusted strong performance persistence. In addition, top performing LBO show a concave relationship with fund rising ${ }^{9}$ and they choose to raise less capital than they could, most likely because of the limited scalability of other inputs like human capital skills such as time and advice.

A similar performance pattern (a persistent performance) is expected within the population of diversified firms. This research does not aim to determine if "on average" the diversification creates or destroys value or what type relatedness is better for shareholder value, but to show that diversification might be a consistent strategy to create a persistent shareholder value and to try to explain this performance pattern through internal efficient funds allocation and the degree of relatedness among business segments. The research aims therefore to demonstrate that (i) there exists a persistence in performance heterogeneity among diversified by measuring the shareholder value creation of diversified firms using alternative methods than the excess value methodology and (ii) to measure the impact of the efficient internal capital market and of the degree of relatedness of segments in the explanation of the persistence of outstanding performance and shareholder value creation.

This paper is organized in the following manner: Section 1 tests the persistence of performance heterogeneity among diversified firms through different econometrics indicators, and tests for the presence of firms' specific effects; Section 2 classifies diversified firms into 3 classes (upper tercile, medium tercile, lower tercile) according to their performance measure through their Markov conditional probability to remain in the same performance tercile or to migrate to the

\footnotetext{
${ }^{9}$ The authors explain that top performer funds, by growing relatively less rapidly than the market on a performance basis adjusted, avoid moving into regions or investment of diminishing returns: mediocre performing funds grow proportionally faster than the top funds.
} 
other two terciles; Section 3 computes and compares the market shareholder value for the top and lower tercile of diversified firms according to the risk and return indicators, the Jensen's alpha and the Fama and French's three factors model; Section 4 attempts to explain the reasons of the difference and persistence of performance using the instrumental variables (IV) system GMM dynamic panel data (Arellano and Bond, 1991). Independent variables are developed to represent (i) the "efficiency" of the internal capital market according to Shin and Stulz (1998), and (ii) the degree of relatedness of the segments' portfolio of the diversified using entropy indicators (Jacquemin and Berry, 1979; Papelu, 1985), Herfindahl index and count-of-the industry indicators constructed on the NAICS code rather than the SIC code. NAICS code classification has been introduced in 1987 in response to the criticisms of the SIC classification, and they have been developed under a production-oriented or supply-based conceptual framework, implying that similar production process will be grouped together; in addition, the NAICS classification takes into consideration new end emerging industries. Within each section of the paper the findings are discussed. Finally, Section 5 concludes.

\section{Data and Sample Selection}

The new segment reporting standard SFAS 131 was issued by the Financial Accounting Standards Boards (FASB) in June 1997 and is effective for fiscal years commencing after December 15, 1997. According to the SFAS 131, a firm needs to report disaggregated information by line of business unless they organize themselves that way for purposes of performance evaluation. In addition, the information provided under the new standard about segment definition would be less subjective than what was provided under the previous SFAS 14 , and it induces companies to more fully reveal their diversification and fund transfer strategies hence reflecting any underlying agency problem (Berger and Hann, 2003). A sample of 164 diversified firms with turnovers higher than $\$ 1$ billion taken from Compustat Industry Segment (CIS) during the 1999-2006 period is examined. The length of this time series (8 years) is justified by the aim of the research question, which is to compare diversified firms that remained diversified during the entire time period. A longer time series (e.g. 15-20 years) may introduce potential self-selection biases given that poor performing diversified firms may choose to refocus into one business as an improving performance strategy (Wernerfelt and Montgomery, 1988), leaving the sample with only good performing multibusiness firms. Firms that refocus and remain refocused are not taken into consideration, and because of the research question, multi-business firms that miss one or more year data are not included into the sample. To compare to other studies, firms belonging to agriculture (SIC 100-900), regulated industry (SIC 4900-4999), financial services (SIC 6000-6900) and SIC 8888, (depositary receipts) SIC 9721 (International affair) and SIC 9995 (non-operating establishment) are excluded. Multisegment firms may not fully allocate accounting items to their reported business segments. This lack of consistency in reporting may induce a problem with the use of business segment data. It is therefore adopted the Berger and Ofek's (1995) convention of requiring that the sum of segment sales (assets) be within 1\% (25\%) of the consolidated firm total reported in the Compustat. For those firms meeting the above criteria, it is then explicitly allocated any unallocated assets: for example if firm level assets are 10\% smaller (larger) than the sum of the segment assets, then each segment's assets are reduced (increased) by 10\%. Moreover, the corporate segment data (sales, assets, capital expenditure, operating income and depreciation) is allocated to the segments on an asset-weighted basis. These adjustments should decrease the shortcomings highlighted by Berger and Hann (2003) in the use of SFAS 131. Because the 
excess value methodology is not used, in contrast to the literature in finance, firms that have segments in the financial industry or in a regulated industry are not dropped altogether, just that particular segment is dropped from the analysis. Around 13 companies of the sample have activities in the financial industry; most of the time the financial segment is a profitable activity (and not sophisticated) of credit and leasing given the interest spread between the cost of debt of the diversified firms and the lending interest. Hence, dropping these types of firms may introduce a bias in the sample selection given that diversified firms enjoy greater debt capacity, lower cost of debt, and debt tax shield relative to single segment firm due to lower risks (Lewellen, 1971; Mansi and Reeb, 2002).

\section{Section 1: Identification of Performance Measurements and Persistence of Performance Heterogeneity}

\section{Variables}

In order to compare performance of firms with segments in different industries with different industry specific performance, the performance indicator used here is the outstanding performance (outstanding with the meaning of above the industry average): a firm that has the sum of the asset-weighted average of the outstanding performance of its segments positive is considered outstanding. There are three indicators of performance: OROA, OSALES/ASSETS, and 0OP/SALES that measure performance in ROA, sales and operating profits relative to industry averages, respectively:

1) OROAit $=\sum_{j=1}^{n}\left(R O A_{j i t}-R O A_{i n d j t}\right) x\left(\frac{A_{j i t}}{A_{i t}}\right)$

With ROAjit representing the ROA of the industry $j$ defined at 6 digit NAICS code of the segment of firm $i$ during period $t$ and with ROAindjt representing the asset-weighted average ROA of the same industry $j$ during period $t$. Ajit /Ait represents the portion of the asset of segment $j$ within firm $i$ during period $t$. In order to compute a consistent benchmark ROAindjt, following the previous literature in finance for the computation of the excess value methodology (Berg and Ofek, 1995), at least 5 segments with the same industry defined at 6 digits NAICS code are required. If this condition is not fulfilled, the industry is then defined at 5 digits NAICS code and the following 4 digits NAICS code until this conditions is fulfilled.

With the same logic as the OROAit, the other two additional indicators of performance are constructed: the ratio sales/assets and the ratio operating profit/sales:

2) OSALES/ASSETS it $=\sum_{j=1}^{n}\left(\frac{S A L E S_{j i t}}{A S S E T_{j i t}}-\frac{S A L E S_{i n d j t}}{A S S E T_{i n d j t}}\right) \times\left(\frac{A_{j i t}}{A_{i t}}\right)$

with SALESindjt/ASSETindjt that represent the asset-weighted average SALES/ASSET ratio of the same industry $j$ during period $t$. 
3) $00 \mathrm{P} / \mathrm{SALES}$ it $=\sum_{j=1}^{n}\left(\frac{O P_{j i t}}{S A L E S_{j i t}}-\frac{O P_{i n d j t}}{S A L E S_{i n d j t}}\right) x\left(\frac{A_{j i t}}{A_{i t}}\right)$

with OPindjt/ASSETindjt that represents the asset-weighted average operating profit/sales ratio of the same industry $j$ during period $t$.

Table I summarizes the descriptive statistics of the three performance indicators. On average, diversified firms do not underperform their industry for all the three indicators of performance.

\section{Table I}

Descriptive Statistics of the Performance Indicators

Three measures of performance are developed: outstanding ROA (OROA), outstanding Sales/Assets (OSALES/ASSETS) and outstanding Operating Profit/Sales (OOP/SALES). They allow comparing the performance of diversified firms in different industry assessing if the segments of a diversified firm performs below or above industry averages. From the descriptive statistics, it is possible to observe that, on average, diversified firms neither outperform nor underperform their industries, but rather are close to 0 . In contrast, the value of the standard deviation indicates that there is an important variability around the average, and that the average value is probably not the most important measure when looking at the performance of diversified firms.

\begin{tabular}{lcc}
\hline Performance indicator & \multicolumn{1}{c}{ Mean } & Std. Dev. \\
\hline OROA & -0.0053985 & 0.0729536 \\
OSALES /ASSETS & 0.0193536 & 1.0492040 \\
OOP/SALES & -0.0009245 & 0.2293588 \\
\hline
\end{tabular}

\section{Test of persistent performance}

To test the persistence of the performance, first we used an autoregressive model AR(1) like:

$Y i t=\alpha+\beta Y i(t-1)+(\eta i+v i t)$

We tested according to several econometric measurements. Yit is the observation of the performance indicators of firm i in period t; Yit- 1 is the performance of the previous period; $\eta \mathrm{i}$ is the stochastic unobserved firm-specific time invariant effect which allows for heterogeneity in the means of the Yit,; and vit is the error component and $\alpha$ is the constant term. The value of $\beta$ is estimated using different econometric measurements and the Hausman test (null hypothesis $\mathrm{E}[\mathrm{Y}$ it $\eta i]=0$ ) is performed.

\section{Table II}

Autoregressive Model AR(1) and Hausman Test for Fixed Effect

To test the persistence of performance, an autoregressive model AR(1) such as Yit $=\alpha+\beta Y i(t-$ 1) $+(\eta i+v i t)$ is tested according to several econometric measurements. To select the most efficient econometric model, the Hausman test (null hypothesis $E[Y i t \eta i]=0$ ) is performed to assess the presence of a firm's time invariant specific effect. For all three performance indicators, the Hausman test rejects the null hypothesis, hence the pooled OLS is rejected and the persistence of performance is computed through the WG indicator and the Two-Stage 
Least Squared (2SLS), developed by Anderson and Hsiao (1981). For the three performance indicators of OROA, OSALES/ASSETS and OOP/SALES, there is empirical evidence of persistence of performance.

\begin{tabular}{|c|c|c|c|}
\hline & Pooled OLS & Within Group & Instrumental Variables 2SLS \\
\hline $\begin{array}{l}\text { OROA } \\
\text { Adjusted } \mathrm{R}^{2}\end{array}$ & $\begin{array}{l}0.7311^{*} \\
0.44\end{array}$ & $\begin{array}{l}0.2852^{*} \\
0.1157\end{array}$ & $0.3760^{\star}$ \\
\hline & Hausman test (WG/GLS) & & $x^{2}=250.95^{*}$ \\
\hline $\begin{array}{l}\text { OSALES/ASSET } \\
\text { Adjusted } \mathrm{R}^{2}\end{array}$ & $\begin{array}{l}0.8544^{*} \\
0.8142^{*} \\
\text { Hausman test (WG/GLS) }\end{array}$ & $\begin{array}{l}0.4887^{*} \\
0.2507^{*}\end{array}$ & $\begin{array}{l}1.109^{*} \\
x^{2}=236.39^{*}\end{array}$ \\
\hline $\begin{array}{l}\text { OOP/SALES } \\
\text { Adjusted } \mathrm{R}^{2}\end{array}$ & $\begin{array}{l}0.3421^{*} \\
0.10^{\star *} \\
\text { Hausman test (WG /BG) }\end{array}$ & $\begin{array}{c}-0.0570+\dagger \\
0.0032 \dagger \dagger\end{array}$ & $\begin{array}{l}0.2213 \dagger \\
x 2=366.68^{*}\end{array}$ \\
\hline
\end{tabular}

${ }^{*} p<0.001{ }^{* *} p<0.01 \quad+p<0.1 \quad+\dagger p<0.5$

Table II demonstrates that all the autoregressive models AR(1) show a consistent value of $\beta$, which confirms the hypothesis of a consistent persistence performance for all three performance indicators. In addition, the rejection of the null hypothesis of the Hausman test represents an additional indication of the correlation between the performance Yit and firm time invariant specific effect $\eta i$. The correlation between Yit and $\eta i$ indicates that the consistent estimation of $\beta$ is represented only by model 3 through the autoregressive first difference, Two-Stage Least Squared (2SLS) developed by Anderson and Hsiao (1981), in which the firm-specific effect is eliminated, hence the estimator is consistent. As suggested by Bond (2002) and Arellano (2003), model 1, AR(1) through pooled OLS is inconsistent and biased upwards since the explanatory variable Yit-1 is positive correlated with the error term $(\eta i+v i t)$ due to the presence of the firm time invariant specific effect $\eta i$. Model 2, the Within Group estimator, eliminates the sources of inconsistency by transforming the equation to eliminate the firm time invariant specific effect $\eta i$; however, this transformation introduces a negative correlation of order $1 /(t-1)$ between the transformed lagged dependent variables and the transformed error term, suggesting that except for time series with $t$ is bigger or equal 15 (Arellano, 2003), the Within Group estimator is biased downwards and hence not efficient. In section 4, an additional consistent and more efficient indicator of $\beta$ than the Two-Stage Least Squared (2SLS) is computed following an IV system GMM dynamic panel data.

\section{Section 2: Diversified Firms Class Composition}

In order to confirm the persistence of performance and to calculate the creation and/or destruction of shareholder value, all diversified firms are sorted into performance terciles. The Markov conditional probability indicates that a multi-business firm will either stay in the same performance tercile, or move into one of the other two terciles with equal probabilities. For all three performance indicators, persistence at both ends of the distribution is found. 


\section{Table III}

Markov Conditional Probability

In order to move from the persistence of performance measured through accounting data, to measurement of market value in terms of creation and/or destruction of shareholder value, all diversified firms are sorted into performance terciles and the Markov conditional probability that indicates that a multi-business firm will either stay in the same performance tercile or move into one of the other two terciles. For all three performance indicators, strong empirical evidence is found of the persistence at both ends of the distribution. The figures below allow constructing top tercile and lower tercile portfolios of diversified firms, and calculating their performance in terms of risk and return.

\begin{tabular}{lrrr}
\hline OROA & & & \\
\hline & Top Tercile (\%) & Medium Tercile (\%) & Lower Tercile (\%) \\
Top Tercile & 72 & 21 & 7 \\
Medium Tercile & 22 & 52 & 26 \\
Lower Tercile & 7 & 28 & 65
\end{tabular}

\section{OSALES/ASSETS}

Top Tercile Medium Tercile Lower Tercile

OOP/SALES

Top Tercile

Medium Tercile

Medium Tercile

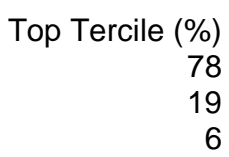

Medium Tercile (\%)

16
59
22

Medium Tercile (\%)

Top Tercile (\%)
Lower Tercile (\%)
6
22
72

Lower Tercile (\%)

20

For all the three performance indicators, diversified firms in the top (and bottom) terciles have at least a $65 \%$ chance of remaining in those terciles, and at most a $9 \%$ chance of moving to the bottom (and top) tercile. This result on the Markov conditional probability allows measuring the shareholder value creation and destruction of diversified firms, and especially its persistence without using the excess value methodology (Berg and Ofek, 1995). Two portfolios with shares of firms that belong to the distribution tail and that persistently remain in that particular distribution tail during the 1999-2006 time series are constructed: for every year two portfolios are built, one portfolio contains shares of the firms that belong to the top tercile, and the other portfolio contains shares of the firms that belong to the lower tercile.

For all performance indicators, the Markov conditional probability indicates a strong persistence of performance, but in order to select the most representative indicator of outstanding performance and construct more representative portfolios of top and lower terciles, each indicator of outstanding performance constructed in section 1 is regressed against firm's Tobin's $q$. Table IV indicates that the OROA indicator has the higher correlation value in comparison to other two indicators defined in section 1 . This is also confirmed by the value of the correlation between the firm's Tobin's $q$ and the level of simple assets weighted average ROA of the firm. 


\section{Table IV}

Simple Regression Among Outstanding Performance Variables and Tobin's $q$

Table III shows that, for all three indicators of performance, the Markov conditional probability shows strong empirical evidence. In order to select the more appropriate performance indicators to construct portfolios of top and lower terciles, each indicator is regressed against the Tobin's $q$ in comparison to the other two indicators, OSALES/ASSETS and OOP/SALES. The following table shows that the OROA has a higher correlation with the Tobin's $q$, hence the portfolios of top and lower diversified firms will be built according to the ranking on the OROA indicators.

\begin{tabular}{llllll}
\hline & OSALES/ASSETS & OOP/SALES & OROA & Tobin's $\boldsymbol{q}$ & ROA \\
\hline OSALES/ASSETS & 1 & & & & \\
OOP/SALES & 0.0028 & 1 & & & \\
OROA & 0.1352 & 0.0646 & 1 & & \\
Tobin's $q$ & 0.0284 & 0.0127 & 0.2248 & 1 & 1 \\
ROA & 0.0878 & 0.0420 & 0.6504 & 0.3379 & 1 \\
\hline
\end{tabular}

\section{Section 3: Portfolio Performance, Risk and Shareholder Value}

Given some of the criticisms of the excess value methodology (Campa and Kedia, 2002; Graham, Lemmon, and Wolf, 2002; Mansi and Reeb, 2002; Villalonga, 2004a, 2004b; Emms and Kale, 2006; Stowe and Xing, 2006) it would seem more appropriate to compute the creation or destruction of shareholder value in a different way. Based on the results of Sections 1 and 2, which indicate a persistence of the performance among multi-business firms, for every year two portfolios are constructed according to the OROA indicator of performance, the first portfolio with firms that belong to the top tercile and the second portfolio with firms that belong to the lower tercile. The Markov conditional probability of Table III, which shows a 72\% probability of a top tercile firm remaining within the same group and a 65\% probability of a lower tercile firm remaining within the same group, will give a good consistency of the results based on these portfolios.

Two equally balanced portfolios ( $\$ 1$ invested in each firm) are constructed and the return to shareholders is evaluated.

\section{Risk and total return}

For each portfolio and for every year, the total return of the portfolio and its standard deviation $(\sigma)$ as measurement of risk is computed. Table $\mathrm{V}$ shows that the portfolio built on the top tercile has a statistically significant higher performance than the portfolio constructed on the lower tercile: over six years, the top tercile portfolio outperforms lower the tercile portfolio with equal return and lower risk, with higher return and equal risk, or with higher return and lower risk. During the last two years, the positive difference between top and lower terciles portfolios is not statistically significant. 


\section{Table V}

Shareholder Value of Top and Lower Terciles: Total Return and Standard Deviation

Based on the empirical evidence of the Markov conditional probability, for each top and lower tercile, and for every year a portfolio is constructed, the total return of the portfolio and its standard deviation $(\sigma)$ as measurement of risk is computed. At the bottom of the table, the difference in performance and risk between the two portfolios and its statistical significance at 95\% ( $t$ statistics indicated in brackets) is computed, as well as the statistical significance ( $p$ value) of the inequality of the standard deviations $(\sigma)$ as measurement of risk. The financial performance of top tercile portfolio is superior and statistically significant to the lower tercile portfolio during the 1999-2004 period (higher return and same risk, same return and lower risk, or higher return and lower risk). For the last two years (2005-2006), the higher return and lower risk of the top tercile portfolio does not reach the statistical significance requested.

\begin{tabular}{|c|c|c|c|c|c|c|c|c|}
\hline & 1999 & 2000 & 2001 & 2002 & 2003 & 2004 & 2005 & 2006 \\
\hline \multicolumn{9}{|l|}{ TOP TERCILE } \\
\hline Total return & 5.31 & 3.56 & 10.29 & -8.00 & 32.68 & 23.15 & 14.65 & 14.97 \\
\hline $\begin{array}{l}\text { Standard deviation }(\sigma) \\
\text { LOWER TERCILE }\end{array}$ & 13.04 & 17.71 & 22.03 & 16.98 & 12.89 & 12.07 & 12.40 & 12.82 \\
\hline Total return & 3.28 & -4.30 & 5.56 & -21.05 & 33.55 & 14.35 & 11.75 & 11.35 \\
\hline $\begin{array}{l}\text { Standard deviation }(\sigma) \\
\text { (TOP - LOWER) }\end{array}$ & 16.36 & 17.36 & 25.95 & 19.29 & 17.39 & 14.41 & 13.22 & 14.56 \\
\hline Total return & $\begin{array}{r}2.03 \\
(0.6608)\end{array}$ & $\begin{array}{r}7.86 \\
(2.2290)\end{array}$ & $\begin{array}{r}4.73 \\
(0.9726)\end{array}$ & $\begin{array}{r}13.05 \\
(3.6302)\end{array}$ & $\begin{array}{r}-0.87 \\
(0.2895)\end{array}$ & $\begin{array}{r}8.8 \\
(3.3668)\end{array}$ & $\begin{array}{r}2.9 \\
(1.1372)\end{array}$ & $\begin{array}{r}3.62 \\
(1.2532)\end{array}$ \\
\hline Standard deviation $(\sigma)$ & $-3.32^{*}$ & 0.35 & $-3.92^{\star \star}$ & -2.31 & $-4.5^{\star}$ & $-2.34^{\star \star}$ & -0.82 & -1.74 \\
\hline
\end{tabular}

\section{Jensen's alpha}

Jensen's alpha (Jensen, 1969) measures the systematic risk-adjusted excess return with respect to a selected market of reference according to the formula:

$\mathrm{R} p-\mathrm{R} f=\beta p(\mathrm{R} m-\mathrm{R} f)+$ Alpha

Alpha $=\mathrm{R} p-\beta p(\mathrm{R} m-\mathrm{R} f)-\mathrm{R} f$

$\mathrm{R} p$ represents the return of the top and lower tercile portfolio's return; $\mathrm{R} f$ is the riskfree rate, $\mathrm{R} m$ is the market returm and $\beta p$ is the covariance of the portfolio's returns scaled by the variance of the return on the market.

The Jensen's alpha is computed according to two markets of reference (market indexes): the Dow Jones Industrial and the SEtP 500 Composite. The data is taken on weekly basis, which yields 52 observations per year. 


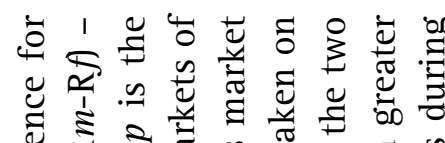

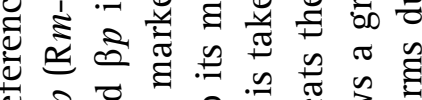

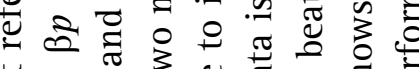
प 1 ह

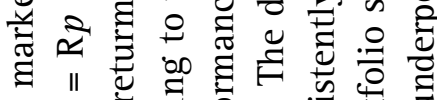
๙

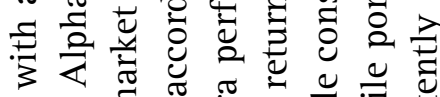
产.

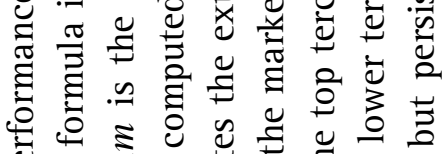

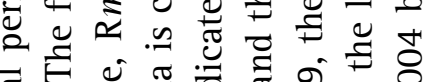

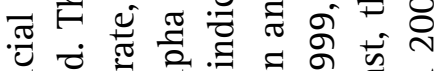
ㅁ⿺辶寸

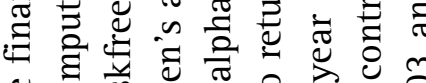

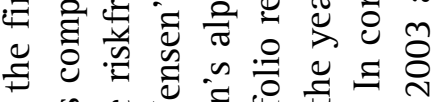

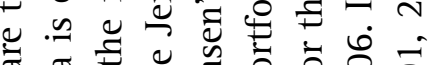

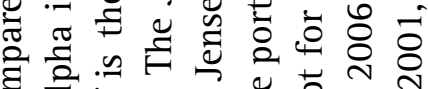

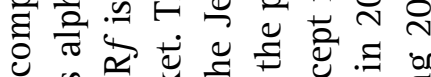
을

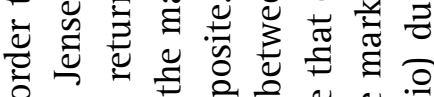

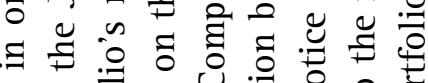

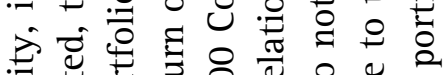

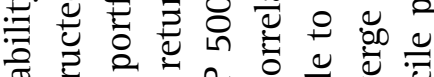

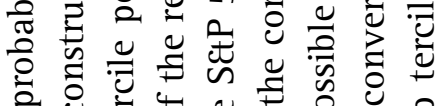

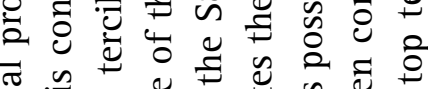
哥 으

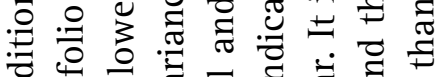

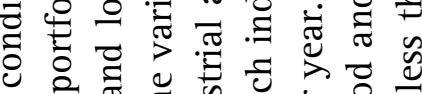

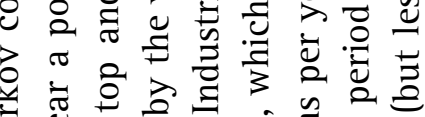

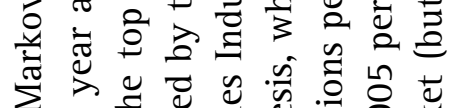

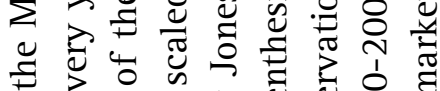
紱

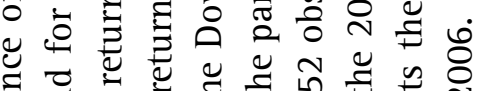

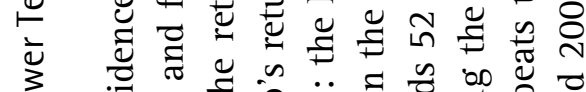
3.

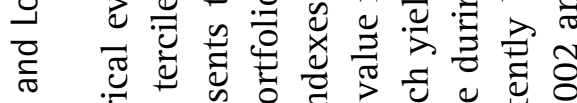
응

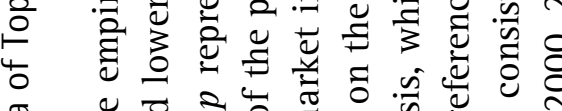

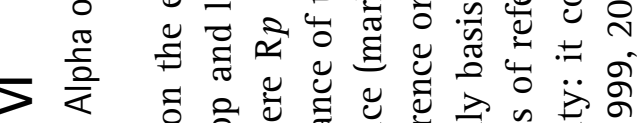

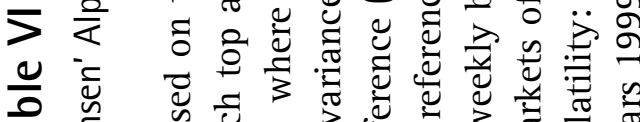

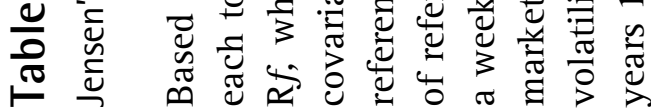

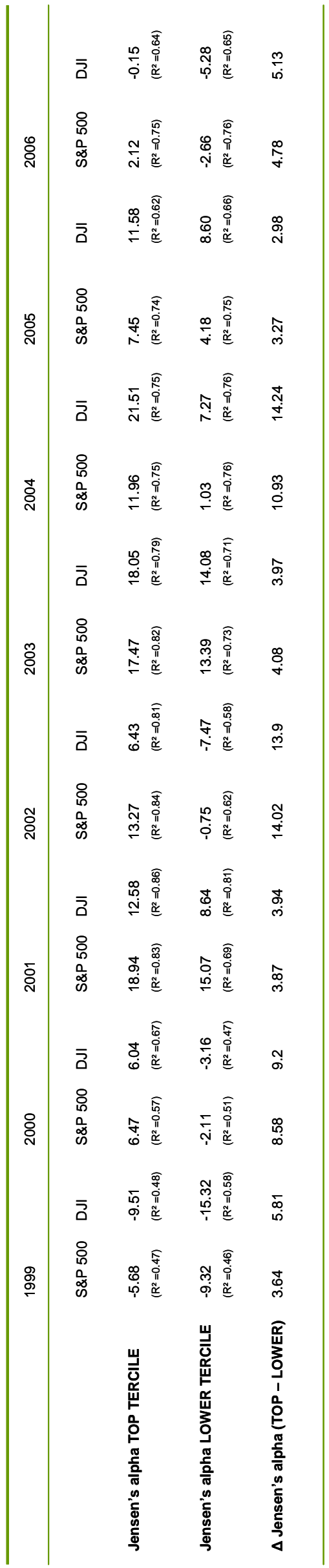


From Table VI it is possible to conclude that the difference and persistence of performance found in Section 1 is reflected as well at shareholder value level. The difference of the Jensen's alpha between the top tercile portfolio and the lower tercile portfolio is always positive. Comparing the performance of the two portfolios with the market performance through the Jensen's alpha, with the exceptions for the years 1999 (Jensen's alpha with negative value) and 2006 (Jensen's alpha close to 0), the top tercile portfolio consistently and constantly beat the market, while the lower tercile portfolio has a consistent negative value of $\alpha$ during four years over the period. This result shows that if "on average" a diversified firm destroys value (Lang and Stulz, 1994; Berg and Ofek, 1995), taking into consideration the persistence of performance, top tier diversified firms show "on average" a strong and persistent shareholder value creation.

\section{Fama and French Three Factors Model}

To attain a deeper understanding of the returns and the type and characteristics of firms that belong to the two portfolios, each portfolio is regressed against the Fama \&t French three factors model for every year of the time series. This multifactor model was motivated by the empirical finding that size (SMB) and the ratio of book to market equity (HML) have consistent and significant explanatory power of stock returns (Fama and French, 1992).

The Fama and French three factors model follows this formula:

$\mathrm{R} p=\mathrm{R} f+b i(\mathrm{R} m-\mathrm{R} f)+s i \mathrm{SMB}+h i \mathrm{HML}$

with:

Factor Rm-Rf: market premium, equal to the CAPM (Sharpe, 1964). This measurement allows comparing the systematic risk known as the market risk, or the risk that cannot be diversified away, not specific to individual stock, for both portfolios.

Factor SMB: It stands for Small Minus Big. This factor accounts for "size premium" and conditionally it is also related to profitability (Fama and French, 1992). It is designed to measure the additional return investors have historically received by investing in stocks of companies with relative small market capitalization. Logically, this factor is expected to be more sensitive to many risk factors as a result of their relatively undiversified nature and their reduced ability to absorb negative financial stock. Fama and French (1992) notice that the recession of 1981 and 1982 turns into a prolonged earning depression for small stocks and for some reason, they notice that on average small stocks do not participate in the boom of the middle and late 1980s.

Factor HML: It stands for High Minus Low. This factor accounts for "value premium" and it is more related to profitability than the SMB factor (Fama and French, 1992). It is designed to measure the additional return provided to investors for investing in companies with high bookto-market values. Fama and French (1995) show that book-to-market equity and the slope on HML proxy for relative for distress: weak firms with persistently low earnings tend to have high BE/ME (book equity market equity ratio) and positive slope on HMT, while strong firms with persistently high earnings have low (BE/ME) and negative slope to HML. 
Table VII shows the results.

\section{Table VII}

Fame and French Three Factors Model

Based on the empirical evidence of the Markov conditional probability, for each top and lower tercile and for every year a portfolio is constructed and regressed against the Fama and French three factors model, according to the formula $\mathrm{Rp}=\mathrm{Rf}+\mathrm{bi}(\mathrm{Rm}-\mathrm{Rf})+\operatorname{siSMB}+$ hiHML. The results below show the following: according to the first factor of Fama and French (the marker index), top tier portfolio of diversifiers show a lower systematic risk than lower tier diversifiers. The second factor, SMB, represents the "premium size," designed to measure the additional return investors have historically received because of the sensitive nature of small capitalization to many risk factors as a result of their relatively undiversified nature and their reduced ability to absorb negative financial stock. The results show that during the entire time series (1999-2006) the lower tercile portfolio shows greater correlation than the top tercile portfolio. Given that in our sample only diversified firms with turnovers greater than $\$ 1$ billion have been included, it is possible to conclude that lower tercile have a lower diversification or a strong "relatedness diversification" in terms of cash flow volatility, while top tercile portfolio seems to contains more unrelated diversification in terms of cash flow volatility. The third factor, HML, account for "value premium" and it is more related to profitability than the SMB factor (Fama and French, 1992). It is designed to measure the additional return provided to investors for investing in companies with high book-to-market values. The result of the regression confirms the result of Table V and VI: top tercile portfolio consistently outperforms the lower tercile portfolio.

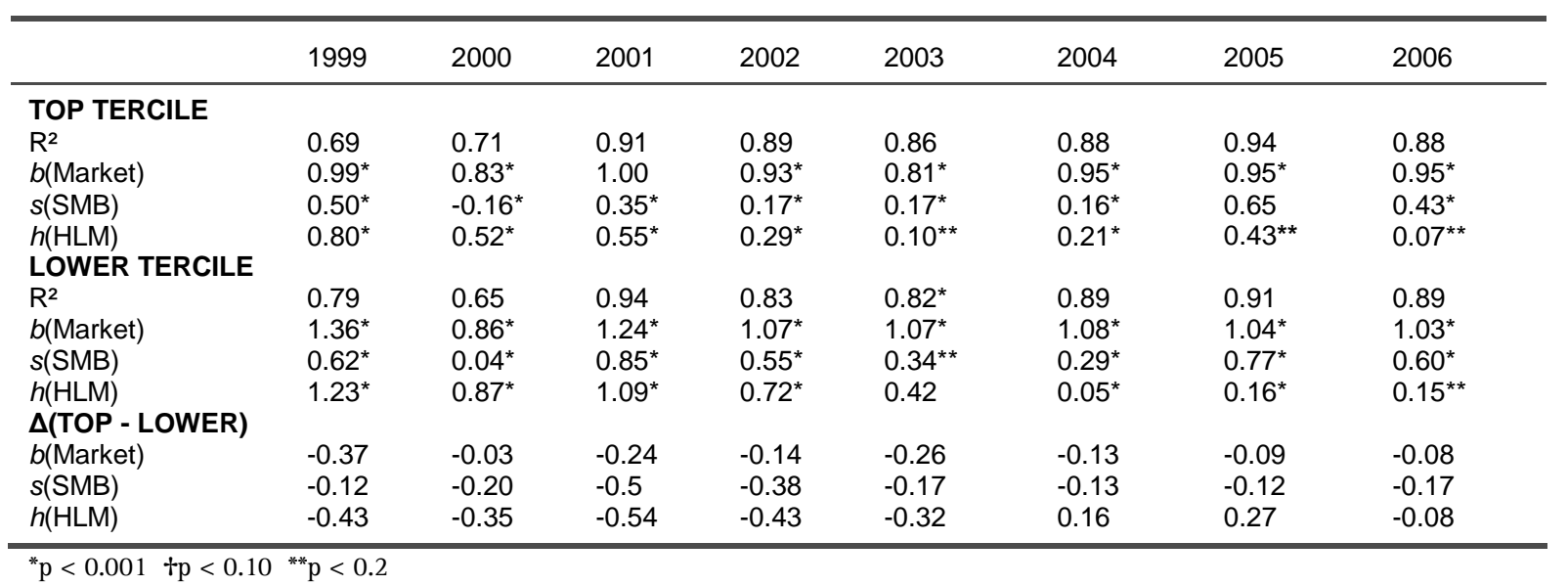

For all three factors of the Fama and French model, coefficients related to the top terciles portfolio are smaller than the lower tercile portfolio for almost the entire 1999-2006 time series. The first factor from the model, the CAPM $b i(\mathrm{R} m-\mathrm{R} f)$ shows that the portfolio constructed on the top tercile shows a lower systematic risk than the portfolio constructed on the lower tercile. 


\section{Figure I}

Systematic Risk ( $\beta$ ): Top Tercile and Lower Tercile

Based on the empirical evidence of the Markov conditional probability for each top and lower tercile and for every year a portfolio is constructed and regressed against the Fama and French three factors model according to the formula $\mathrm{R} p=\mathrm{R} f+b i(\mathrm{R} m-\mathrm{R} f)+s i \mathrm{SMB}+h i \mathrm{HML}$. According to the first factor of Fama and French (the marker index), top tercile portfolio of diversifiers show a lower systematic risk than lower tier diversifiers.

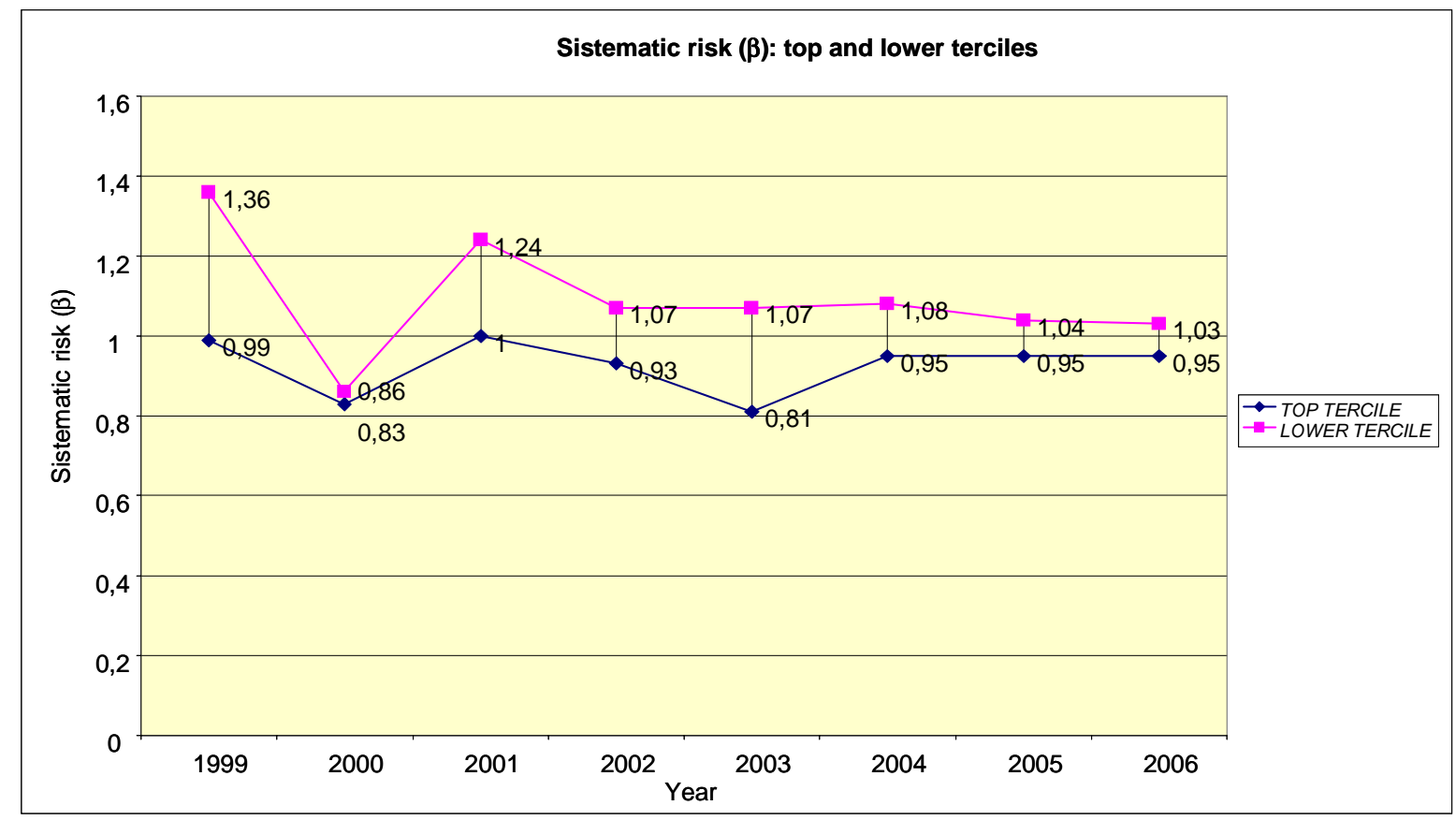

The second factor from the model siSMB represents the "size premium," which indicates the additional return investors have historically received by investing in stocks of companies with relative small market capitalization given their reduced ability to absorb negative financial stock, explained also by their lower degree of diversification which increases cash flow volatility. The sample of diversified firms included only diversifiers that have a sales turnover of at least $\$ 1$ billion every year, hence small capitalization should not have been included. However, when comparing siSMB within the top tercile compared to the lower tercile (Figure II) it is possible to affirm that, without analyzing the degree of relatedness among business segments, diversified firms that belong to the lower terciles have more small-capitalization characteristics than diversified firms that belong to the top terciles, especially in term of cash flow volatility. This finding also provides information on the degree of segment relatedness: under the assumption that the degree of earning relatedness is positively correlated to the degree of segment relatedness, the more related the segments are, the lower the performance of the diversified firm. 


\section{Figure II}

Fama and French SMB Factor: Top Tercile and Lower Tercile

The figure below indicates the coefficient $\operatorname{siSMB}$ of the Fama and French 3 factor models of both portfolio of top tercile and lower tercile during the 1999-2006 time series. Lower tercile portfolio is consistently higher than the top tercile portfolio, suggesting that lower tercile firms compared to the top tercile firms possess more characteristics of medium-size firms, such as: higher difficulty to react to shocks' market, lower degree of diversification and higher earning volatility.

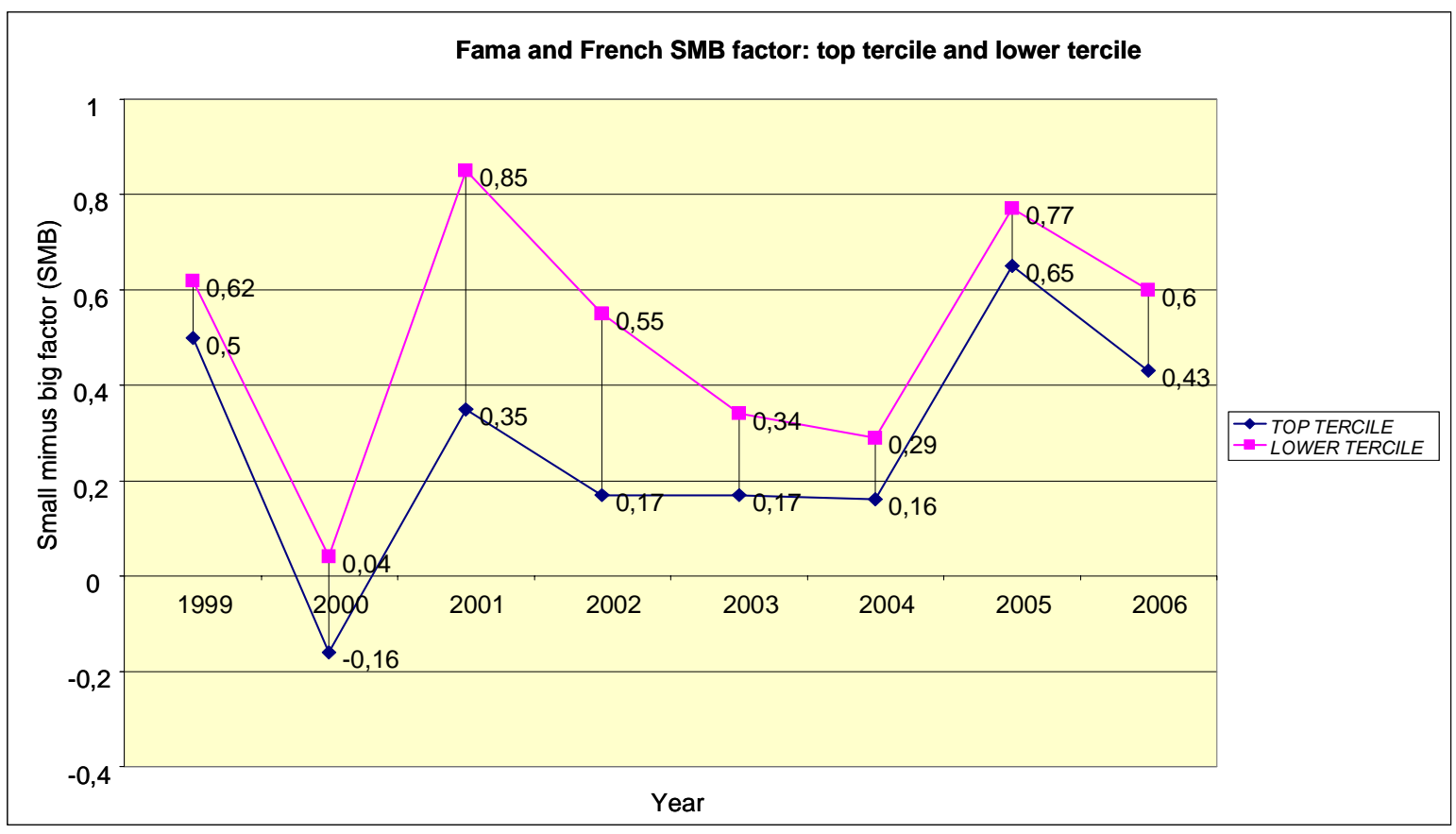

The third factor from the model siHML represents the "value premium," which is more related to profitability than the SMB factor (Fama and French, 1992). The lower coefficients found for the top tercile portfolio, in comparison of the lower tercile portfolio, confirm the previous findings in the risk return and Jensen's alpha analyses: top tercile portfolio possess higher performance compared to the lower tercile, and in two years the value of the slope for top tercile is negative while always positive for the lower tercile portfolio.

The comparison of the values of (i) the risk and total return, (ii) the Jensen's alpha, and (iii) the HML factor of the Fama and French model confirms that the persistent outstanding performance is also present through market-based indicators. These results also confirm the accounting performance measure OROA used to construct top and lower portfolios. 


\section{Section 4: Outstanding Performance, Efficient Internal Capital Market and Degree of Relatedness Among Business Segments}

Findings in Sections 1, 2 and 3 demonstrate that some multi-business firms continuously outperform and create a positive shareholder value compared to the market. As explained in the review of financial literature, the main justification for the diversification discount among diversified firms is mainly driven by the degree of efficiency of the internal capital market; the diversification discount is mainly explained by a motivation of misallocation of internal funds of destruction of cash flow where higher profitable segments subvention lower profitable segments. In contrast to the strategy field, the literature focuses the explanation of the outperforming or underperforming multi-business firms mainly on the degree or relatedness among business segments, or by the ability to develop synergies among businesses.

This section attempts to explain, using panel data, the outstanding performance (OROA) through independent variables that represent (i) the degree of efficiency of the internal capital market according to the conditions of efficiency of Shin and Stulz (1998) and (ii) the degree of segments' relatedness of the diversified firm.

\section{Econometric model selection and development}

The selection of the econometrics model needs to take into account two critical considerations: (i) the presence of the time invariant firm's specific effect $\eta i$, given that in Section 1 the Hausman test shows that $\mathrm{E}[\mathrm{Y} i \mathrm{i} \eta i] \neq 0$; and (ii) the length of the eight-year time series (19992006) which makes the standard candidate in case presence of $\eta i$, (the Within Group indicator) inefficient because of the negative correlation of order $1 /(t-1)$ between the transformed lagged dependent variables and the transformed error term. Arellano and Bond (1991) suggest, for a mean stationary process where $\mathrm{E}[\Delta \mathrm{Y} i t \eta i]=0$, using the dynamic panel data model with the instrumental variables (IV) system generalized method of moments (GMM) that eliminates firm's specific effect and gives efficient value of parameters for large sample and limited time series. In addition, this econometric model allows the researcher to attempt to manage the endogeneity related to the independent variables with the use of longer lags as instruments when needed. The sample selected is composed by large multi-business firms with turnovers greater than $\$ 1,000$, hence it is correct to assume that the delta performance $\Delta$ Yit of the firms in the sample selected follows a mean stationary process.

The static econometric model is

$$
\mathrm{Y} i t=\beta i \mathrm{X} i+(\eta i+v i t)
$$

Where Yit is the outstanding ROA (OROA) indicator that has been used to build the two portfolios of top and lower terciles in Section 3, Xit are the independent variables that represent the degree of efficiency of the internal capital market and the degree of relatedness among business segments; $\eta i$ is the stochastic unobserved firm-specific time invariant effect; and vit is the error component or disturbance term, for simplification of writing the constant term is omitted. Consistent estimation of $\beta i$ requires that the static equation in (1) is transformed into a dynamic representation. To do that, the equation in (1) at (t-1) is multiplied by $\alpha$ to get: 


$$
\alpha \mathrm{Yi}(t-1)=\alpha \beta i \mathrm{Xi}(t-1)+(\alpha \eta i+\alpha v i(t-1))
$$

Then, the difference between these two equations (1) and (2) is computed to obtain the new dynamic econometric equation under the following representation:

$$
\mathrm{Yit}=\alpha \mathrm{Yi}(t-1)+\beta i \mathrm{Xit}-\alpha \beta i \mathrm{Xi}(t-1)+[(1-\alpha) \eta i+v i t+\alpha v i(t-1)]
$$

This last equation (3) is the input equation used in the IV system GMM (Arellano and Bond, 1991). Through this dynamic representation, the value of $\alpha$, which is the coefficient of the past performance, will be also estimated through a more efficient model than the 2SLS econometric measurement in Section 1, given that we have a time period greater than three years (Bond, 2002; Arellano, 2003).

\section{Independent variables development}

Independent variables are developed to represent the efficiency of the internal capital market and the degree of relatedness among business segments.

\section{Efficient internal capital market}

Shin and Stulz (1998) develop three conditions for an efficient internal capital market: (i) it gives priority in the allocation of funds to the segments with best investment opportunities; (ii) the segment's investment is less sensitive to its own cash flow as well as to other segments' cash flows; and (iii) the allocation of funds to a segment falls when other segments have better investment opportunities.

The first and third conditions deal with the firm's performance hence, the following control variables are developed to test these conditions.

a) To test the first condition, the allocation of funds to the best performing segments, the following indicators are developed:

$\operatorname{MAXMAXit}=\left[\sum_{j=1}^{n}\left(I_{j i t}+D I S_{j i t}\right)\right] /\left[I_{i t}-D I S_{i t}\right]$

Where Ijit is the investment in segment $j$ of the firm $i$ in time $t$ hence the positive of the results of the following formula ${ }^{10}$ : ASSETjit + DEPRECIATIONjit - ASSETji(t-1). Using the same logic, DISjit is the disinvestment but has a negative value. In the denominator, the investments (Iit) minus the disinvestments (DISit) of the firm $i$ during time $t$ is considered because it aims to represent the whole amount of the investment and disinvestment decisions of the firm. The numerator only considers investments and disinvestments within segments that have both the ROA > assets weighted ROA of the firm $i$ during period $t$ as well as $>$ the ROAindjt, which represents the asset-weighted average ROA of the industry $j$ in which the segment operates during period $t$.

\footnotetext{
${ }^{10}$ The CAPEX field is not used as indicator of investment because it misses important components of the investments within diversified firms such as the acquisitions, which are a common investment strategy within diversified firms (Maksimovic and Phillips, 2006).
} 
$\operatorname{MIMIN} i t=\left[\sum_{j=1}^{n}\left(I_{j i t}+D I S_{j i t}\right)\right] /\left[I_{i t}-D I S_{i t}\right]$

Where Ijit is the investment in segment $j$ of the firm $i$ in time $t$ hence the positive of the results of the following formula ${ }^{11}$ : ASSET jit + DEPRECIATIONjit - ASSET ji $(t-1)$. With the same logic, DISjit is the disinvestment, but it has a negative value. In the denominator, the investments (Iit) minus the disinvestments (DISit) of the firm $i$ during time $t$, is considered because it aims to represent the whole amount of the investment and disinvestment decisions of the firm. The numerator only considers investments and disinvestments within segments that have the ROA < assets weighted ROA of the firm $i$ during period $t$ and $<$ the ROAindjt which represents the asset-weighted average ROA of the industry $j$ in which the segment operates during period $t$.

According to the first condition of internal capital market's efficiency of Shin and Stulz (1998), it a positive coefficient of MAXMAX is expected (investment in highly performing segments with ROA above both the industry and firm's average) and a negative coefficient of MINMIN (disinvestment in low performing segments with ROA below both the industry and firm's average). Additional two intermediary independent variables are constructed MAXMIN (investments and disinvestments within segments that have the ROA > ROA of the firm $i$ during period $t$ but $<$ ROAindjt) and MINMAX (investments and disinvestments within segments that have the ROA $<$ ROA of the firm $i$ during period $t$ but $>$ ROAindjt), but given their construction, no significant statistical representation is expected from these two last independent variables.

b) To test the third condition, the CFINV variable is developed, in which allocation to specific segments falls when other segments have better investment opportunities:

CFINVit $=\left[\sum_{j=1}^{n}\left(I_{j i t}+D I S_{j i t}\right)\right] /\left[I_{i t}-D I S_{i t}\right]$ which works according to the logic described in the variable CFGROWTHjit.

CFGROWTHjit $=\left(I_{j i t}+D I S_{j i t}\right) *\left[\left(C F_{j i t} / A_{j i t}\right) /\left(C F_{j i(t-1)} / A_{j i(t-1)}\right)-\sum_{j=1}^{n}\left(C F_{-j i t} / A_{-j i t}\right) /\left(C F_{-j i(t-1)} / A_{-j i(t-1)}\right)\right]$

which behaves according to the following logic:

- If CFGROWTHjit $>0$ than $\left(I_{j i t}+D I S_{j i t}\right)$ of the segment $j$ is computed in the numerator of CFINVit.

- If CFGROWTHjit $<0$ than $\left(I_{j i t}+D I S_{j i t}\right)$ of the segment $j$ is set to 0 in the numerator of CFINVit.

Ijit is the investment in segment $j$ of the firm $i$ in time $t$, hence the positive results of the following formula: ASSETjit + DEPRECIATIONjit - ASSETji(t-1). With the same logic, DISjit is 
the disinvestment but with a negative value. The denominator only considers the investments (Iit) minus the disinvestments (DISit) of the firm $i$ during time $t$, because it aims to represent the whole amount of the investment and disinvestment decisions of the firm.

CFGROWTH takes into consideration if investment and disinvestment decisions are efficient: a positive value of this indicator means that (i) an investment has been performed because the profitability of the segment under the formula [CFjit/Ajit] / [CFji(t-1)/Aji(t-1)] is higher compared to the rest of the portfolio under the formula $\sum_{j=1}^{n}\left(C F_{-j i t} / A_{-j i t}\right) /\left(C F_{-j i(t-1)} / A_{-j i(t-1)}\right)$

or (ii) a disinvestment has been performed because the profitability of the segment is lower compared to the rest of the portfolio, while a negative value of CFGROWTH indicates an opposite behavior, hence it is considered as an inefficient funds allocation. CF is the cash flow of the segment (the sum of the operating profit plus depreciation), $-j$ represents the total segments of the firm minus the segment $j$, and $(t-1)$ represents one lag period. A is the value of the assets allocated to the segment.

According to the third condition of internal capital market's efficiency of Shin and Stulz (1998), the value of CFINV tends to $1(100 \%$ of the investment and disinvestment decisions are efficient). In contrast, within an inefficient internal capital market, the value of CFINV tends to 0 ( $0 \%$ of the investment and disinvestment decisions are efficient). Overall, it is expected to have a positive correlation between the independent variable CFINV and the dependent variable OROA.

\section{Degree of segment relatedness}

Here, in order to assess the validity of the inverted-U curvilinear relationship between diversification and performance, the use of sophisticated indicators of relatedness that are able to tap into the degree of relatedness among business segments is not preferred, but they may ask scholars for a degree of subjectivity (Martin and Sayrak, 2003). The following indicators will be used: (i) Herfindahl index, (ii) simple count-of-industry approach, and (iii) entropy indicators (Jacquemin and Berry, 1979; Papelu, 1985). An additional argument for not using sophisticated indicators of relatedness is also motivated by the times series selected and the use of the NAICS codification. In the time series selected (1999-2006), segments' information is disclosed according to the new segment reporting standard SFAS 131 in which the firm needs to report disaggregated information by line of business, unless they organize themselves that way for purposes of performance evaluation. Hence, it induces companies to more fully reveal their diversification and fund transfer strategies. In addition, the information provided under the new standard about segment definition would be less subjective than what was provided under the previous SFAS 14 (Berger and Hann, 2003). Finally, the use of the NAICS code rather than the SIC code permits capturing a certain portion of the degree of relatedness among business segments because of their construction logic.

The indicators are:

HERFINDAHL INDEXit $=1-\sum_{j=1}^{n} S_{j i t}^{2} \quad$ where $\mathrm{S}=\mathrm{SALESjit} / \sum_{j=1}^{n}$ SALES $S_{j i t}$ 
DTit (Diversification Total entropy indicator of firm $i$ in time $t)=\sum_{j=1}^{n} P_{j} \ln \left(1 / P_{j}\right)$ where $P_{j}$ is the proportion of business (sales) of segment $j$ defined at 6-digits NAICS code.

DUit (Diversification Unrelated entropy indicator of firm $i$ in time $t)=\sum_{j=1}^{n} S_{j} \ln \left(1 / S_{j}\right)$ where $S_{j}$ is the proportion of business (sales) of segments $j$ defined according to the first 3-digits NAICS code.

DRit (Diversification Related entropy indicator of firm $i$ in time $t$ ) $=$ DTit - Duit.

NBSEGit $=$ Number of segments reported by firm $i$ in time $t$.

NBSECit $=$ Number of subsectors defined at the first 3 digits of the NAICS code of firm $i$ in time $t$. NBINDit $=$ Number of industries defined at the first 4 digits of the NAICS code of firm $i$ in time $t$. Moreover additional control variables are included as the leverage (LEVERAGE), log of assets (ASSETS) and dividend per share (DIVIDEND/SHARE).

The results of the instrumental variables (IV) system GMM econometric models are shown in Table VIII. 


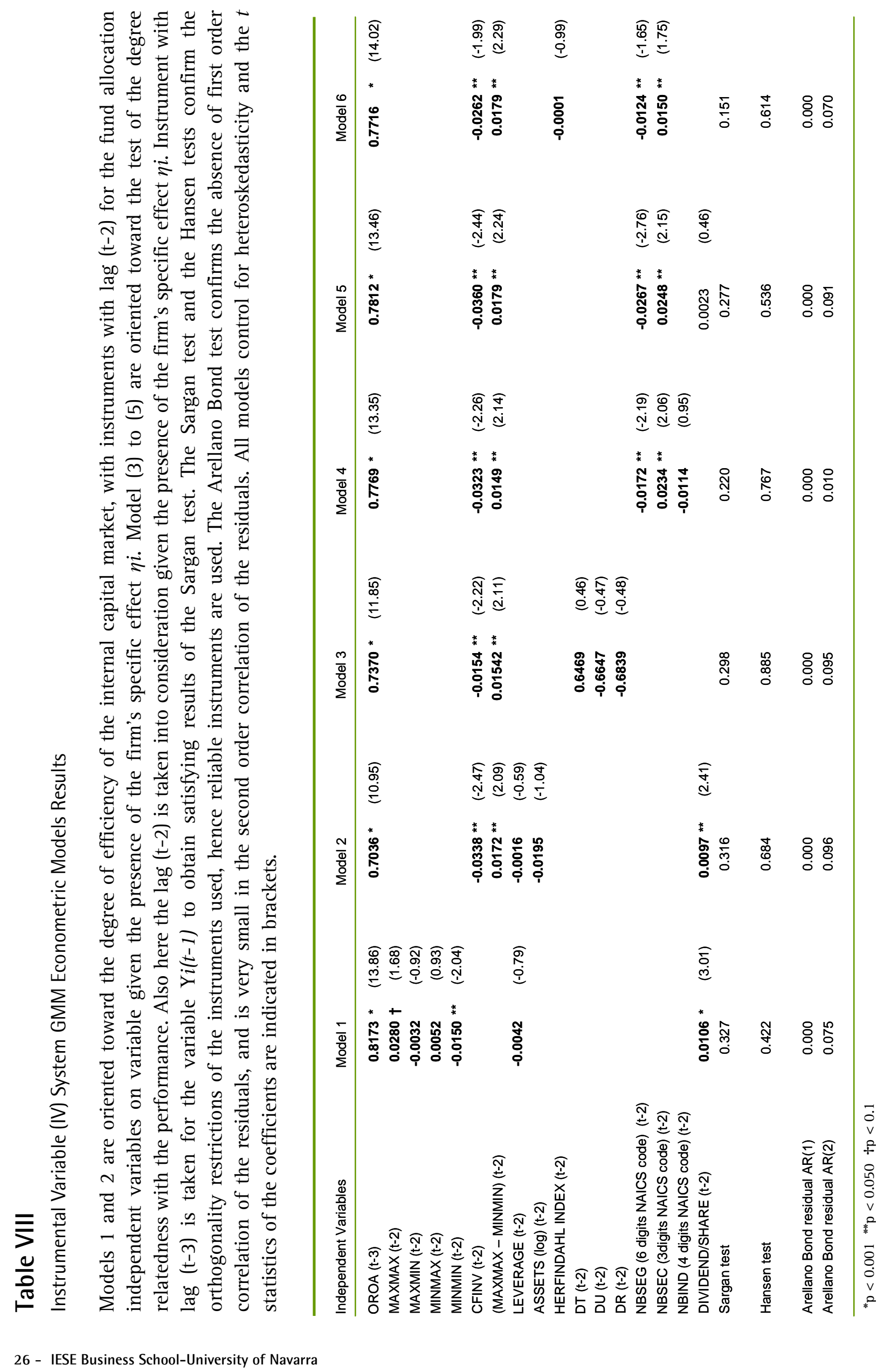


All six models confirm a strong persistence of outstanding performance based on the outstanding ROA (OROA) indicator through coefficient $\beta$ Yit-1 within the interval $[0,70-0,81]$, higher than the value found in Section 1 through the Anderson and Hsiao first difference 2SLS estimation (close to 0,40). The explanation of the past performance factor is much higher than (i) the degree of efficiency of the internal capital market (the coefficients $\beta i$ for the independent variable MAXMAX is 0,028 and for MINMIN is -0,015), and (ii) the degree of relatedness among business segments (the coefficients $\beta i$ for the independent variable NBSEC is between 0,015 and 0,0248 and for NBSEG is between $-0,012$ and $-0,0267$ ).

For all models, the values of the Sargan and Hansen tests as well as the Arellano Bond autoregression test $A R(1)$ and $A R(2)$ of the residuals [absent for AR(1) and insignificant for AR (2)] confirm the statistical validity of the econometric models. Moreover, all models control for heteroskedasticity.

The findings confirm the first condition of the efficiency of the internal capital market: the allocation of funds to the best performing segment is a direct explanation of the persistence of the performance (independent variable MAXMAX), while the allocation to low performing segments is negatively correlated with performance (independent variable MINMIN). In contrast, the second condition of the efficiency of the internal capital market - the coefficient of CFINV - is statistically significant but with a negative sign: investing in high-performing segments in comparison to the rest of the segment portfolio is negatively correlated with the outstanding performance. There are several possible explanations for this result of CFINV: (i) obtaining an outstanding performance is a difficult task, and the correct direction of the investment to high-performing segments is not sufficient; (ii) Jensen's (1986) agency cost of free cash flow argumentation, in which managers in high-performing firms invest in lower performing segments, but this hypothesis is not confirmed by the firm's leverage variable (LEVERAGE); (iii) managers may invest with greater crtieria when the performance starts deteriorating; and (iv) in order to construct a variable to satisfy the third condition of the efficiency of the internal capital market, this independent variable only compares each segment with the rest of the portfolio without making any distinction between high- and lowperforming segments of the rest of the portfolio.

In terms of the degree of relatedness of business segments, one may observe that both entropy indexes and the Herfindahl index do not reach a statistical significance to confirm the assumed inverted-U curvilinear relationship between diversification and performance. But in Models 4, 5 and 6 , a simple count(?) of the industry approach indicates that if the number of segments (independently of the number of industries) has a negative impact of performance, contrarily the number of industries in which a firm operates has a positive correlation with performance. This last finding (positive correlation between number of industries defined at the first 3 digits NAICS code and outstanding performance) is also confirmed by the finding described in Section III, when regressing the top tercile and lower tercile of diversified firms to the SMB factors of Fama and French three factors model. The top tercile seems to have lower cash flow volatility, hence lower covariance of its cash flow in comparison to the lower tercile. Therefore, by adding the findings in Section III with the findings in Section IV, it is possible to conclude that the top tercile may have a certain degree of unrelated diversification in their portfolio of segments, hence the assumed inverted-U curvilinear relationship between diversification and performance is not confirmed.

Another possible explanation of the business relatedness pattern described above might be suggested by the empirical findings of Campa and Kedia (2002) and Villalonga (2004a), in 
which the "diversification discount" is mainly driven by endogeneity when firms choose a diversification strategy as a path to move from declining industry. Hence, they still perform poorly while within highly and unrelated diversified firms, and the diversification is a path to develop profitable new business opportunities through consolidated and tested procedures for the allocation of internal funds and management of the business segments.

Finally, by comparing the explanatory power of the past performance (controlling for firm's specific effects) to the other independent variables, it is possible to conclude that the positive relationship between diversification and performance goes far beyond the simple explanation of an efficient internal capital market or a certain degree of relatedness among business segments. This suggests that, in order to study the relationship between diversification and performance, more complete models that include firm's strategies, corporate entrepreneurship behavior and management skills should be taken into consideration.

Finally, to improve the significance of the results found in the econometric models, for all dependent and independent variables of the top and lower terciles, we test two independent means for inequality with Student's t test. 


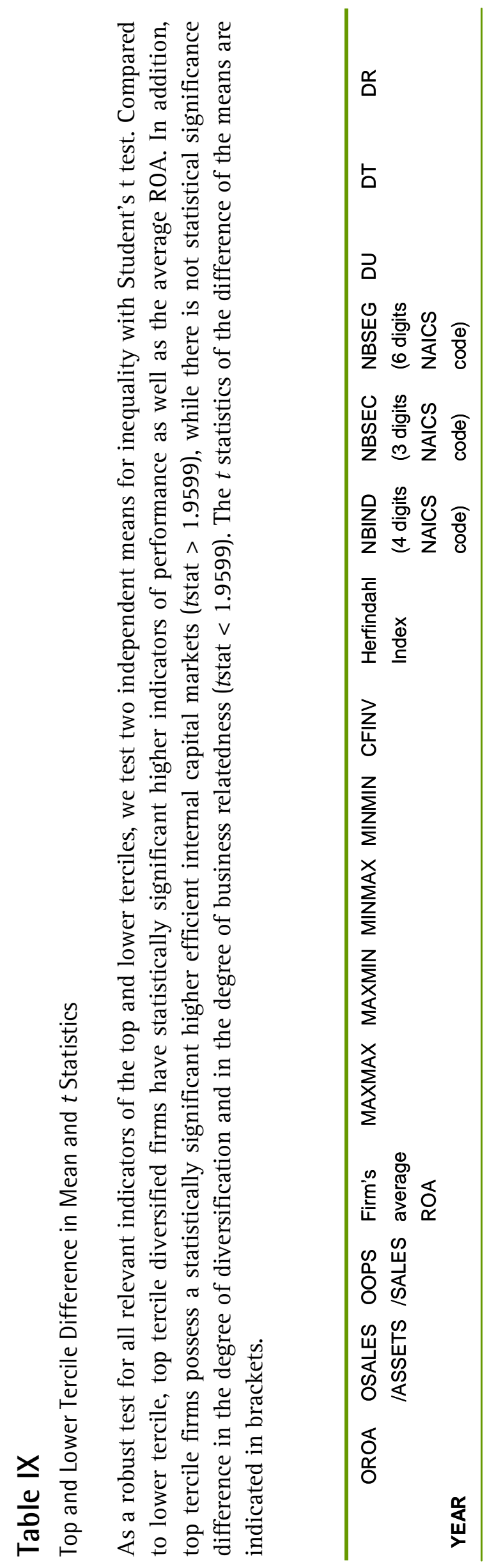

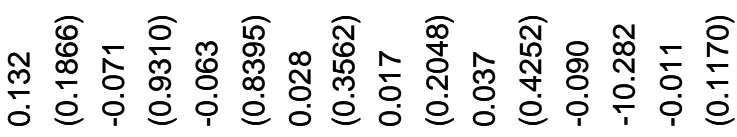

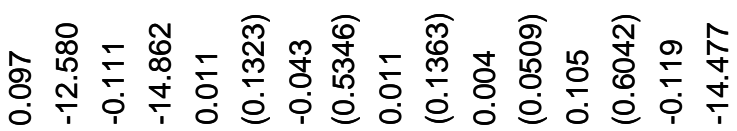

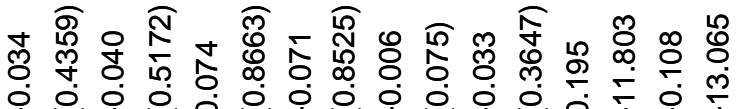
悉 ণ 雨 i 巳

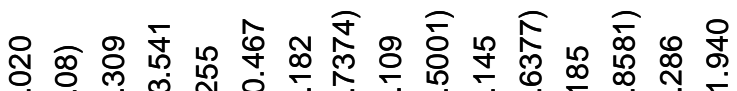

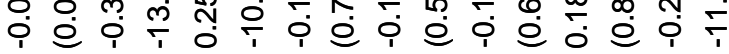

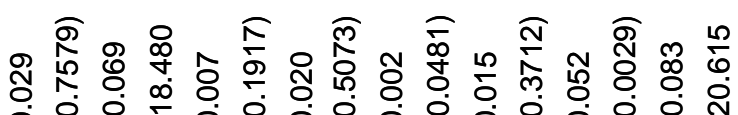
o

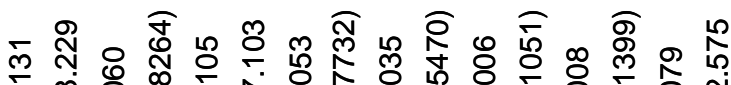

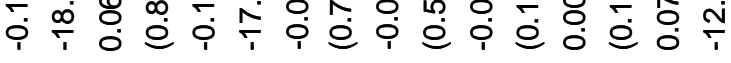

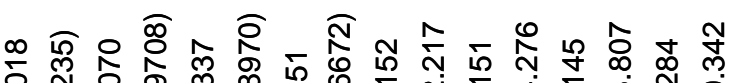

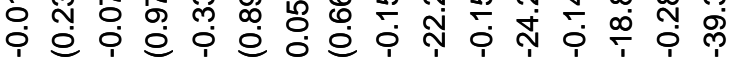

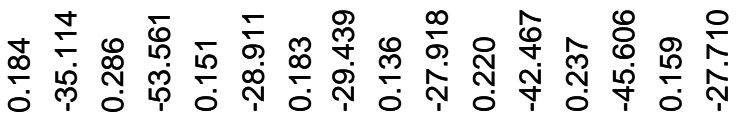

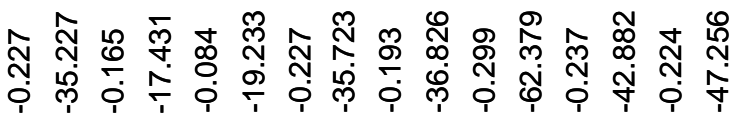

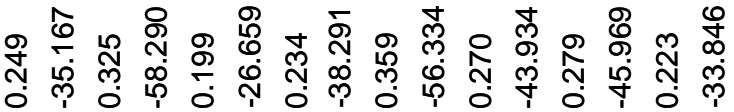

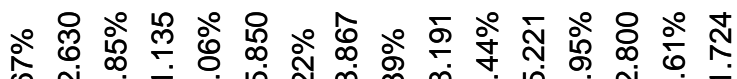

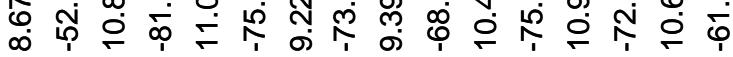
品

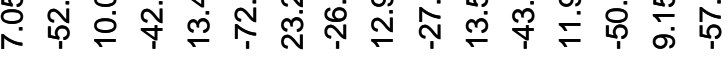

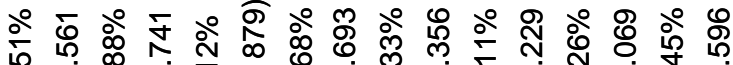

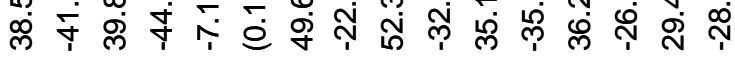

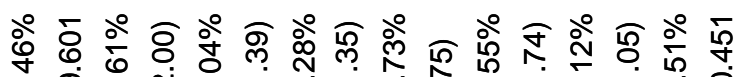

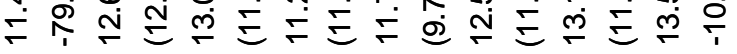

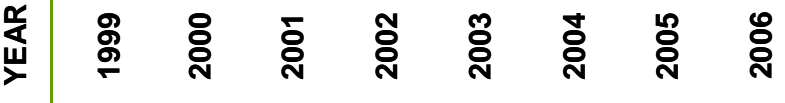


Compared to lower tercile, top-tercile diversified firms have statistically significant higher value for the three industry adjusted indicators of performance during the whole time series: OROA (range from 11.28\% to 13.51\%); OASSETS/SALES (range from 29.45\% to 52.33\%); and 0OP/SALES (range from 7.05\% to 23.28\%). Similar results are found at the firm's average ROA (range from $8.67 \%$ to $11.06 \%$ ).

We find a statistically significant confirmation for the first condition of the efficient internal capital market: top-tercile firms allocate more funds in segments with higher investments opportunities (MAXMAX with range from 19.9\% to 35.9\%) while lower terciles firms invest more in poor performing segments (MINMIN - top tercile minus lower tercile - with range from $-14.5 \%$ to $-28.4 \%$ ). The means' comparison of the indicator CFINV, representing the third condition of the efficient internal capital market, is not statistically significant.

Finally, both terciles do not have a statistically significant means' difference (tstat $<1.9599$ ) for the degree of relatedness among business segments. This indicates, as found previously in the econometrics models, that inverted-U curvilinear relationship between diversification and performance is not confirmed.

\section{Section 5: Conclusion and Direction for Future Research}

Without attempting to answer the classical research questions in finance and strategic management (if a business segment is better off within a diversified firm or alone, and looking for a "content valid" indicator of business relatedness to explain the linkage diversification and performance), but rather measuring shareholder value based on the empirical findings of an important persistence of performance among diversified firms, this research found that some diversified firms create a persistent shareholder value as well as beating the market index. Similar to private equity funds, diversified firms show similar performance pattern: some diversified firms persistently outperform their peers and the market by creating a substantial shareholder value while others constantly underperform.

An efficient internal capital market explains some of the outstanding performance, but it is limited compared to the past performance. Important insights for future research may be drawn from the results that attempt to answer the question of how the persistence of outstanding performance is related to the degree of relatedness among business segments: the inverted-U curvilinear relationship is not confirmed. In contrast, these results indicated that diversified firms with segments in different unrelated industries, defined at 3 digits NAICS code and with lower correlation among segment's earnings, seems to benefit from higher and persistent performance. It is possible to conclude that (i) diversification creates a persistent shareholder value for these types of firms that are able to develop and manage the process of diversification strategy, and that (ii) this persistence of outstanding performance goes far beyond the degree of efficiency in the funds allocation process and the degree of relatedness among business segments.

The results of this research indicate that the study of the linkage between diversification and performance future research should be oriented in the development of additional indicators at both management and diversification strategy path development levels in order to test to what extent the explanation of the outstanding performance pattern of diversified firm resides within the firm's strategy and management capabilities. 


\section{Reference}

Anderson, T. W. and Hsiao C. (1981), "Estimation of dynamic model with error components," Journal of the American Statistical Association, pp. 589-606.

Arellano, M. (2003), "Panel data econometrics," Oxford University Press.

Arellano, M. and Bond, S. R. (1991), "Some tests of specification for panel data: Monte Carlo evidence and an application to employment equations," Review of Economic Studies, 58, pp. 227-297.

Berg, G. B. and Ofek, E. (1995), “Diversification Effects on Firm Value," Journal of Financial Economics, 37, pp. 39-65.

Berger, P. G. and Hann, R. (2003), "The impact of SFAS N0 131 on information and monitoring," Journal of Accounting Research, Vol. 41, pp. 163-223.

Billet, M. and Mauer, D. (2003), "Cross-subsidies. external financing constraints and the contribution of the internal capital market," Review of Financial Studies, 16, pp. 1167-1202.

Bond, S. R. (2002), "Dynamic panel data models: a guide to micro data methods and practice," Portugase Economic Journal, 1, pp. 141-162.

Campa, J. M. and Kedia, R. (2002), "Explaining the diversification discount," Journal of Finance, Vol. 57, No 4, pp. 1731-1762.

Campello, M. (2002), "Internal capital market in financial conglomerates: evidence from small bank response to monetary policy,” Journal of Finance, Vol. 57, No 6, pp. 2773-2805.

Capron, L. and Hulland, J. (1999), "Redeplyment of brands. sales forces. and general marketing management expertise following horizontal acquisition: a resource based-view," Journal of Marketing, 63 (2), pp. 41-54.

Chatterjee, S. and Wernerfelt, B. (1999), "The link between resources and types of diversification: theory and evidence," Strategic Management Journal, 12 (1), pp. 33-48.

Chandler, A. D. (1991), "The functions of the HQ unit in the multibusiness firm," Strategic Management Journal, 12, pp. 31-50.

Denis, D. D., Denis, D. K., and Sarin, A. (1997), "Agency problems. equity ownership. and corporate diversification,” The Journal of Finance, Vol. LII, pp. 111-133.

Emms, E. E. and Kale, J. R. (2006), "Efficiency implications of corporate diversification: evidence from micro data," Working Paper Seattle University CES 06-26.

Fama, E. F. and French, K. R. (1992), “The cross section of expected stock return," Journal of Finance, 47, pp. 427-465.

Fama, E. F. and French, K. R. (1993), "Common risk factors in the returns on stocks and bonds," Journal of Financial Economics, 33, pp. 3-56.

Fama, E. F. and French, K. R. (1995), "Size and book-to-market factors in earnings and returns," Journal of Finance, 50, pp. 131-156. 
Farjoun, M. (1994), "Beyound industry boundaries: human expertise, diversification and resources-related industry groups,” Organizational Science, 39 (11), pp. 1334-1346.

Gaertner, R. H., Scharfstein, D. S., and Stein, J. C. (1994), "Internal versus external capital markets,” The Quarterly Journal of Economics, pp. 1211-1230.

Goold, M. and Campbell, A. (1987), "Strategy and styles," Oxford University Press, Oxford.

Graham, J. R., Lemmon, M. L., and Wolf, R. (2002), "Does corporate diversification destroy value?," Journal of Finance, Vol. 57, pp. 695-720.

Guedji, I. and Sharrfstein, D. (2004), "Organisational scope and investment: evidence from the drug development strategies and performance,” NBER Working Paper 10933.

Hall, H. E. and John, St. (1994), “A methodological note on diversity measurement," Strategic Management Journal, 15 (2), pp. 153-168.

Hill, W. L. (1994), "Diversification and economic performance: bringing structure and corporate management back into the picture," in Rumelt, R. P., Schendel, D. E., and Teece, D. J., "Fundamental Issues in Strategy: a Research Agenda," Boston, Harvard Business School Press.

Hyland, D. C. and Diltz, D. J. (2002), "Why firms diversify: an empirical examination," Financial Management, pp. 51-81.

Ilinitch, A. Y. and Zeithaml, C. P. (1995), "Operationalizing and testing Galbraith's center of gravity," Strategic Management Journal, 16 (5), pp. 401-410.

Jacquemin, A. P. and Berry, C. H. (1979), "Entropy measure of diversification and corporate growth," The Journal of Industrial Economics, 27, 4, pp. 359-369.

Jensen, M. C. (1969), "Risk, the pricing of capital assets, and the evaluation of investment portfolios,” The Journal of Business, Vol. 42, No 2, pp. 167-247.

Jensen, M. C. (1986), "Agency cost of free cash flow, corporate finance and takeovers," American Economic Review Papers and Proceedings, 76, pp. 323-329.

Kaplan, S. N. and Schoar, A. (2005), "Private equity performance: returns, persistence and capital flows," Journal of Finance, Vol. 60, No 4, pp. 1791-1823.

Keiser, K. M. J. and Stouraitis, A. (2001), "Reversing corporate diversification and the use of the proceeds from asset sales: The Case of Thorn EMI," Financial Management, pp. 5-44.

Khanna, N. and Tice, S. (2001), "The bright side of internal capital market," Journal of Finance, 56, pp. 1489-1528.

Lamont, 0. A. and Polik, C. (2001), "The diversification discount: cash flows versus returns," The Journal of Finance, Vol. 56, pp. 1693-1721.

Lang, L. H. P. and Stulz, R. M. (1994), “Tobin's q. corporate diversification and firm performance," Journal of Political Economics, 102, pp. 1248-1280.

Maksimovic, V. and Phillips, G. (2002), "Do comglomerate firms allocate resources inefficiently across industries? theory and evidence,” Journal of Finance, Vol. 57, No 2, pp. 721-767.

Maksimovic, V. and Phillips, G. (2006), "Conglomerate firms and internal capital markets," forthcoming Handbook of Corporate Finance series, Elsevier/North Holland. 
Mansi, S. A. and Reeb, D. M. (2002), “Corporate diversification: what gets discounted?," Journal of Finance, No 5, pp. 2167-2183.

Markides, C. C. and Williamson, P. J. (1994), "Related diversification, core competence and corporate performance," Strategic Management Journal, Summer Special Issue (15), pp. 149165.

Martin, J. D. and Sayrak, A. (2003), "Corporate diversification and shareholders value: a survey of recent literature,” Journal of Corporate Finance, 9, pp. 37-57.

Palich, L. E., Cardinal, L. B., and Miller, C. C. (2000), "Curvilinearity in the diversificationperformance linkage: an examination of over three decades of research," Strategic Management Journal, 21, pp. 155-174.

Papelu, K. (1985) Diversification strategy. profit performance and the entropy measure, Strategic Management Journal, 6 (3), pp. 239-255.

Peyer, U. (2001). "Internal and external capital markets," Working Paper, University of North Carolina at Chaspel Hill.

Prahalad, C. K. and Bettis, R. A. (1986), "The dominant logic: a new link between diversity and performance," Strategic Management Journal, 7 (6), pp. 485-501.

Robin, J. A. and Wiersema, C. F. (1995), "A resource based approach to the multibusiness firms: empirical analysis of portfolio interrelationships and corporate financial performance," Strategic Management Journal, 16, pp. 277-299.

Robin, J. A. and Wiersema, C. F. (2003), "The measurement of corporate portfolio strategy: analysis of the content validity of related diversification indexes," Strategic Management Journal, 24, pp. 39-59.

Rajan, R., Servaes, H., and Zingales, L. (2000), "The cost of diversity: the diversification discount and inefficient investment," Journal of Finance, Vol. 55, pp. 35-80.

Rumelt, R. (1974), "Strategy Structure and Economic Performance," Cambridge MA, Harvard University Press.

Rumelt, R. (1982), "Diversification strategy and profitability," Strategic Management Journal, 3 (4), pp. 359-369.

Santalo, J. and Becerra, M. (2008), "Competition from specialized firms and the diversificationperformance linkage,” Journal of Finance, 63, pp. 852-883.

Scharfstein, D. S. and Stein, J. C. (2002), "The dark side of the internal capital markets: Divisional rent-seeking and inefficient investment," Journal of Finance, 55, pp. 2537-2564.

Schoar, A. (2002), "Effects of corporate diversification on productivity," Journal of Finance, December, Vol. 57, pp. 2379-2403.

Shin, H. H. and Stulz, R. M. (1998), “Are internal capital market efficient?," The Quarterly Journal of Economics, pp. 531-552.

Sharpe, W. F. (1964), "Capital asset prices: A theory of market equilibrium under condition of risk,” Journal of Finance, Vol. 19, pp. 425-442. 
Silverman, B. S. (1999), "Technological resources and the direction of corporate diversification: toward an integration of the resource-based view and transaction cost economics," Management Science, 45 (8), pp. 1109-1124.

Stein, J. C. (1997), "Internal capital market and the competition for corporate resources," The Journal of Finance, Vol. 52, pp. 111-133.

Stowe, J. D. and Xing, X. (2006), "Can growth opportunities explain the diversification discount?," Journal of Corporate Finance, 12, pp. 783-786.

Tanriverdi, H. and Venkatraman, N. (2005), "Knowledge relatedness and the performance of multibusiness firms," Strategic Management Journal, 26, pp. 97-119.

Villalonga, B. (2004), "Diversification discount or premium? New evidence from the business information tracking series," Journal of Finance, Vol. 59, pp. 475-502.

Villalonga, B. (2004), "Does diversification cause the diversification discount?," Financial Management, Vol. 33, pp. 5-27.

White, T. M. (2001), "Is it inefficient investment that causes the diversification discount," Journal of Finance, Vol. 56, pp. 1667-1691.

Williamson, O. E. (1975), "Markets and hierarchies. analysis and antitrust implications," New York, The Free Press.

Williamson, O. E. (1985), “The economic institutions of capitalism,” New York, The Free Press.

Williamson, O. E. (1994), "Strategizing. economizing and economic performance," in Rumelt R. P., Schendel, D. E., and Teece, D. J., "Fundamental Issues in Strategy: a Research Agenda", Boston, Harvard Business School Press.

Wernerfelt, B. and Montgomery, C. (1988), “Tobin's q and the importance of focus in firm performance," American Economic Review, 78 (1), pp. 246-250. 